\title{
Intraspecific variability of the Lygodium sawfly, Neostromboceros albicomus (Konow, 1900) (Hymenoptera, Tenthredinidae, Selandriinae)
}

\author{
Andreas Taeger ${ }^{1}$ \\ I Senckenberg Deutsches Entomologisches Institut (SDEI), Eberswalder Str. 90, 15374 Müncheberg, Germany \\ Corresponding author: Andreas Taeger (ataeger@senckenberg.de)
}

Academic editor: S. Schmidt| Received 29 September 2013 | Accepted 8 October 2013 | Published 25 October 2013

Citation: Taeger A (2013) Intraspecific variability of the Lygodium sawfly, Neostromboceros albicomus (Konow, 1900) (Hymenoptera, Tenthredinidae, Selandriinae). Journal of Hymenoptera Research 35: 91-96. doi: 10.3897/JHR.35.6341

\begin{abstract}
The intraspecific variation of Neostromboceros albicomus (Konow, 1900) in a restricted area in Thailand is described. The value of characters, some of which are used for separating species and species groups in Neostromboceros, is discussed. The male of $N$. albicomus is described here for the first time.
\end{abstract}

\section{Keywords}

Intraspecific variability, Selandriinae, Thailand

\section{Introduction}

Neostromboceros Rohwer, 1912, originally described as a subgenus of Stromboceros Konow, 1885, comprises today 154 nominal taxa of which about 135 are currently considered to be valid (Taeger et al. 2010, and unpublished data). Eighty one (53\%) of the nominal taxa were described after 1998. Most species were recorded from the Oriental and eastern Palaearctic regions, and a few species from Australasia (e.g., Schmidt and Smith 2009).

The identification of Neostromboceros species is difficult, and usually great uncertainties remain. The most comprehensive keys to species were published by Malaise (1944; all known 41 taxa keyed), Saini (2006; 53 taxa from India keyed) and Haris (2006; 24 taxa from Malaysia, Indonesia and Papua New Guinea keyed). 
Smith et al. (2002) discussed $N$. albicomus as a potential biological control agent for the Old World climbing fern, Lygodium microphyllum (Cav.) R. Brown, an invasive species in Florida. According to Rodgers et al. (2012), N. albicomus is still awaiting a permit for use as a biological control agent. As a second host plant, Smith et al. (2002) recorded Lygodium flexuosum (Linnaeus) Swartz. Furthermore, according to Smith et al. (2002) "larvae fed and completed their live cycle on L. salicifolium Presl, but adults did not oviposit on this species". According to Smith et al. (2002) there are two biotypes of $N$. albicomus, each feeding on a different host plant, and genetically differing by a single base in the 28S-D2 rDNA gene region. In the same paper, Smith clarified the synonymy of the species, and synonymized the type species of Neostromboceros, Stromboceros (Neostromboceros) metallica Rohwer, 1912, with N. albicomus. Hitherto, the species is known from Malaysia, Philippines, Singapore, Thailand, and Vietnam (Smith et al. 2002).

\section{Material and methods}

For this study, 39 specimens of Neostromboceros albicomus were examined from Thailand, Chiang Mai Province, collected by Saowapa Sonthichai with Malaise traps, with the following label data:

1-10 August 1997: $18.692^{\circ} \mathrm{N}, 98.816^{\circ} \mathrm{E}, 270 \mathrm{~m}$. Pa Huay Thong: Thambon Nam Bo Luang. Amphur Sampatong (7 9 ).

10-20 August 1997: $18.542^{\circ} \mathrm{N}, 98.954^{\circ} \mathrm{E}, 250 \mathrm{~m}$. Pa Huay Thong: Thambon Nam Bo Luang. Amphur Sampatong, in field at edge of mixed deciduous forest (2 9 ). 1-10 September 1997: Rim Pa Huay Tong, $18^{\circ} 48.07^{\prime} \mathrm{N}, 98^{\circ} 57.27^{\prime} \mathrm{E}\left[=18.801^{\circ} \mathrm{N}\right.$, $98.955^{\circ} \mathrm{E}$ ], $270 \mathrm{~m}$. Thambon Bo Luang [sic!]. Amphur Sampatong, at edge of deciduous forest $\left(11+2{ }^{\Uparrow}\right)$.

10-20 September 1997: Rim Pa Huay Tong, $18^{\circ} 48.07^{\prime} \mathrm{N}, 98^{\circ} 57.27^{\prime} \mathrm{E}\left[=18.801^{\circ} \mathrm{N}\right.$, $98.955^{\circ} \mathrm{E}$ ], $270 \mathrm{~m}$. Thambon Bo Luang [sic!]. Amphur Sampatong, at edge of deciduous forest $(12+, 2$ ภ).

20-30 September 1997: Rim Pa Huay Tong, $18.801^{\circ} \mathrm{N}, 98.938^{\circ} \mathrm{E}, 250 \mathrm{~m}$. Thambon Nam Bo Luang. Amphur Sampatong, in mixed deciduous forest (3 + ).

Photos were taken with a Leica DFC 495 digital camera attached to a M205 C stereo microscope. The penis valve was photographed with a Leica DFC 450 digital camera mounted on an Olympus BX.51 microscope. Extended depth of field images were created with CombineZ5.3 and finally arranged and partly enhanced with Ulead PhotoImpact X3. The pictures reproduced in this paper, as well as views on other specimens, are accessible at full resolution under doi: $10.6084 / \mathrm{m} 9$.figshare. 798854 . The specimens examined are housed in the entomological collection of Utah State University, Logan, USA, and in the Senckenberg Deutsches Entomologisches Institut, Müncheberg, Germany. 


\section{Results}

Of the 39 examined specimens, 19 with partly yellow-red abdomen run in the keys (Malaise 1944, Haris 2006) rather smoothly to $N$. albicomus, whereas 19 specimens with a black abdomen did not fit any of the keyed species. The remaining $39^{\text {th }}$ specimen is a very unusual intermediate female with the abdomen color longitudinally separated in a black left side and a right yellow-red side (Fig. 1a). This specimen strongly supports the hypothesis that the two alternative colorations of the abdomen (below called 'color forms') are a result of color dimorphism of the same species. The fairly large series of specimens was used to check the intraspecific variation of $N$. albicomus in a restricted area (the four localities listed above are no further apart from each other than 30 kilometers):

- Both color forms were found at all four localities; the clypeus is in most cases completely blue-black, but at all localities specimens with a pale marked clypeus also occur (Fig. 1c),

- the depth of the apical emargination of the clypeus varies about between 15 and $30 \%$ of its length (Fig. 1c),

- the pale marked clypeus may be found in both color forms (Table 1),

- specimens with a pale marked clypeus usually also have more extensively pale marked legs,

- the specimens with the palest legs have hind tibiae with more than the basal third pale, whereas in the darker forms only about the basal quarter is pale (Fig. 1e),

- the trochanters become paler from the front to the hind legs,

- the hind trochanters are usually more or less darkened on the inner side, but in pale specimens may also be completely pale; the tegulae are usually completely blue-black, in several specimens the basal area is more or less pale,

- the blue or more or less purple metallic luster is sometimes reduced on larger parts of the body and simply appears black (Fig. 1b),

Table I. Color patterns of clypeus and abdomen in N. albicomus, sorted by collecting event and sex. Intermediate female from 1-10 September not included.

\begin{tabular}{c|c|c|c|c|c}
\hline $\begin{array}{c}\text { collecting event } \\
\text { (date and site) }\end{array}$ & $\begin{array}{c}\text { specimens, } \\
\text { sex }\end{array}$ & $\begin{array}{c}\text { abdomen and } \\
\text { clypeus blue- } \\
\text { black }\end{array}$ & $\begin{array}{c}\text { abdomen blue- } \\
\text { black and clypeus } \\
\text { pale marked }\end{array}$ & $\begin{array}{c}\text { abdomen mainly } \\
\text { pale and clypeus } \\
\text { blue-black }\end{array}$ & $\begin{array}{c}\text { abdomen mainly } \\
\text { pale and clypeus } \\
\text { pale marked }\end{array}$ \\
\hline $1-10$ August & $7 q$ & 2 & 1 & 3 & 1 \\
\hline $10-20$ August & $2+$ & 1 & & 1 & \\
\hline $1-10$ September & 10 + & 1 & 3 & 5 & 1 \\
\hline $1-10$ September & 20 & 2 & & & \\
\hline $10-20$ September & $12+$ & 5 & 1 & 6 & \\
\hline $10-20$ September & 20 & 1 & & & \\
\hline $20-30$ September & $3+$ & 1 & 1 & 1 & \\
\hline
\end{tabular}




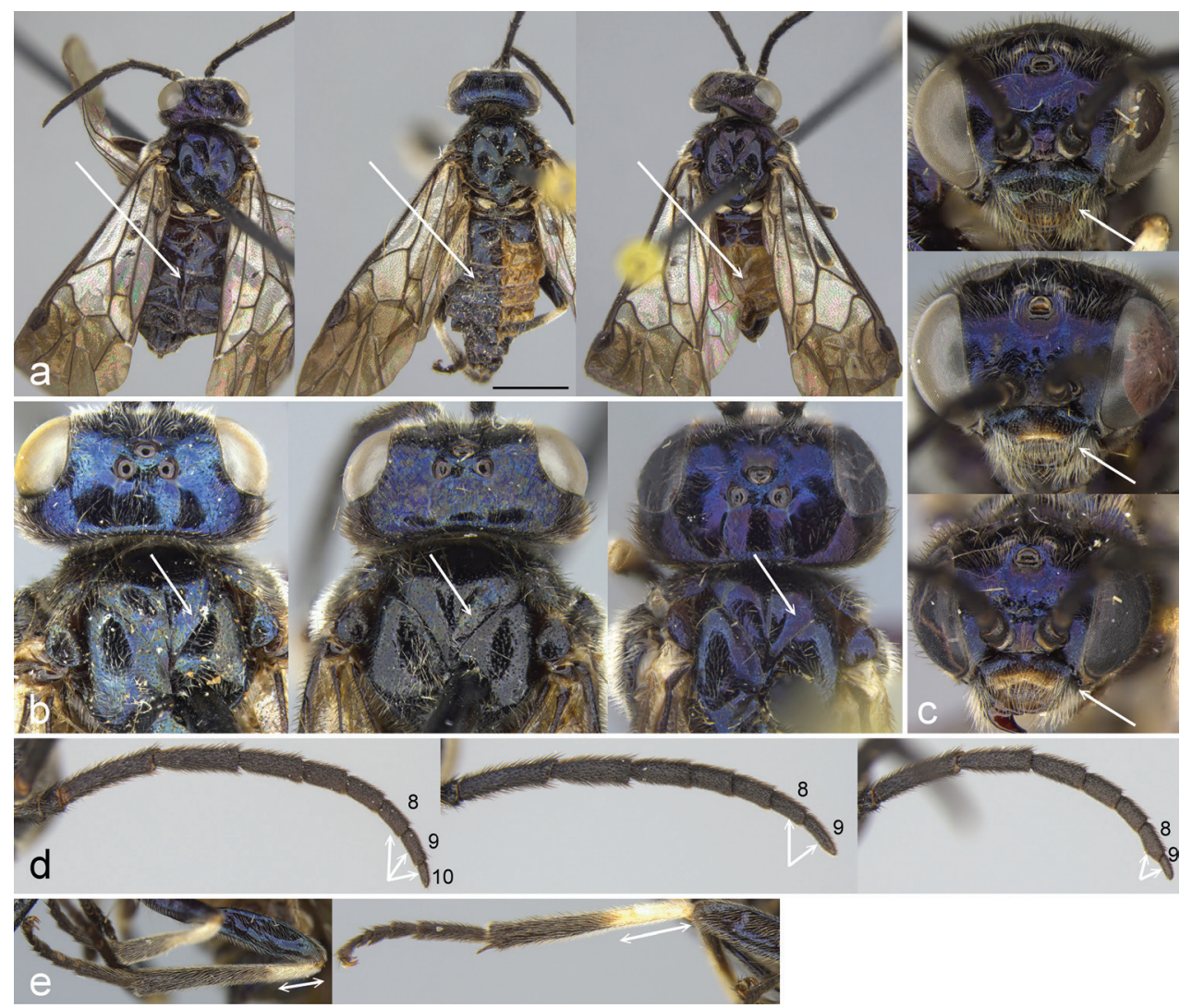

Figure I. Neostromboceros albicomus, various specimens, both sexes. a color of abdomen (females, scale $2 \mathrm{~mm}$ ) b color and density of pits on mesonotum $\mathbf{c}$ color and shape of clypeus $\mathbf{d}$ shape of apical antennomeres e color of hind tibia.

- the size and density of the pits on the thorax and head are variable, but in a large majority of specimens the pits are scattered and small (Fig. 1b),

- the apical antennomeres are variable in size,

- the number of antennomeres is 9 or 10 (Fig. 1d) and frequently differs between antennae of a single specimen,

- intraspecific variation seems to be independent of the sex.

\section{Male}

The male of $N$. albicomus was undescribed (Haris 2006). Among the material discussed above four males were found. Apart from the sexual differences, the male fits the characters of the female, including the variation described above. Smith (pers. comm.) noted that after 2002 he received some males from Thailand, most of them with orange on the abdomen but one more brownish. Images of two males are reproduced in Fig. 2. 


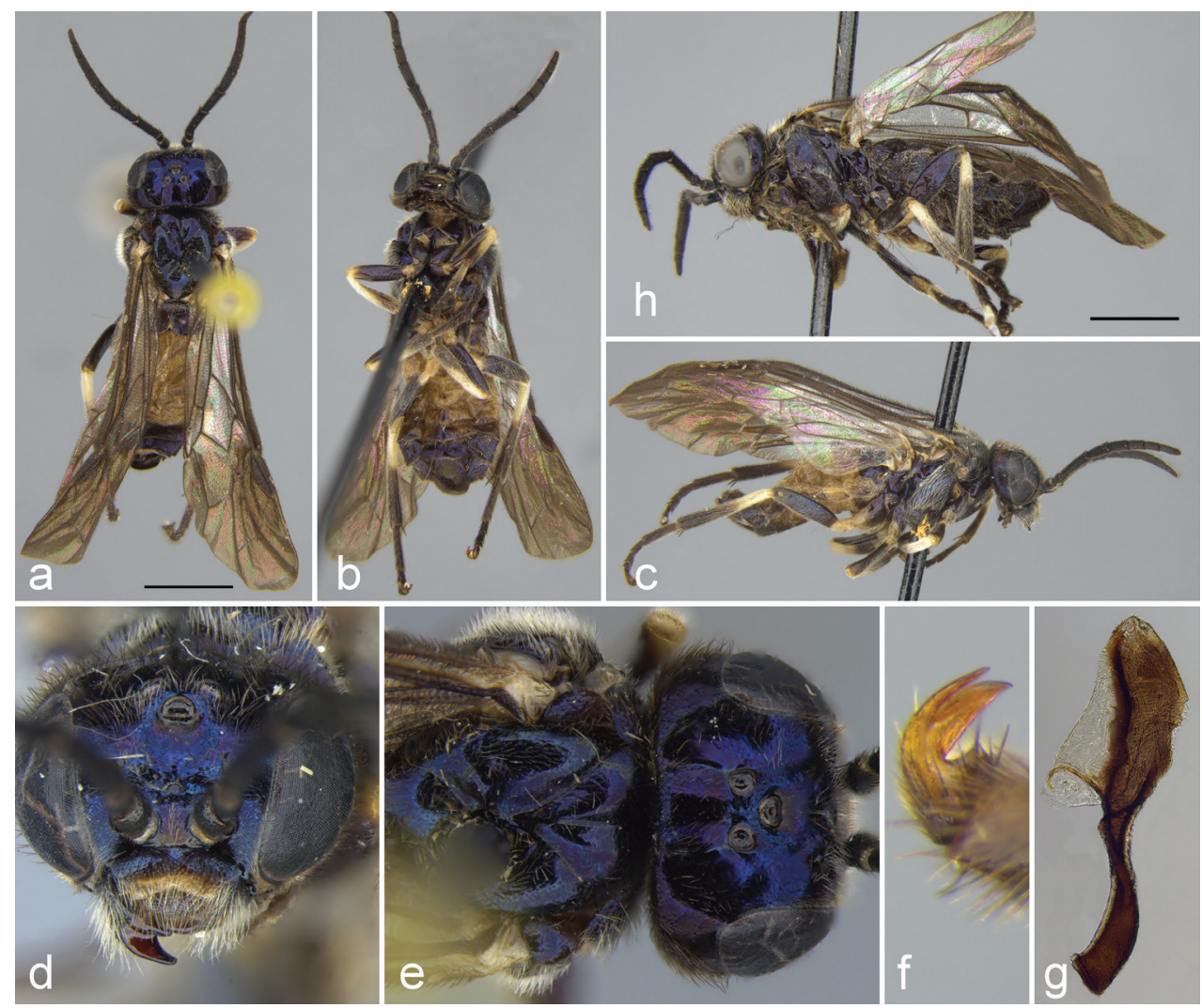

Figure 2. Neostromboceros albicomus, males. a-f pale specimen a dorsal (scale $2 \mathrm{~mm}$ ) b ventral c lateral $\mathbf{d}$ face $\mathbf{e}$ head and thorax, dorsal $\mathbf{f}$ claw of hind leg $\mathbf{g}-\mathbf{h}$ dark specimen $\mathbf{g}$ penis valve $\mathbf{h}$ ventrolateral view (scale $2 \mathrm{~mm}$ ).

\section{Discussion}

The available material revealed an unexpected high level of intraspecific variation in $N$. albicomus. This is an example of a phenomenon that may be more widespread within the taxonomically very difficult genus Neostromboceros. Unfortunately, the characters that were shown to be highly variable are frequently used for the separation of species or species groups in Neostromboceros. The present study demonstrates that the description of new taxa from only few specimens or singletons, a common practice in the past, should be avoided because of the high risk of describing variants of known species. The inclusion of genetic information could help to solve problems related to color variation in the future.

\section{Acknowledgements}

Many thanks to Frank Koch (Berlin), Brian V. Brown and Meiping Xie (Los Angeles, CA) and James Pitts (Logan, UT) who made the material available to me for examination. 
Thanks also to Dave R. Smith (Washington, DC), Stefan Schmidt (Munich), Stephan Blank, Andrew Liston and Marko Prous (Müncheberg) for helpful discussions. A. Liston kindly corrected the English of the paper.

\section{References}

Haris A (2006) New sawflies (Hymenoptera: Symphyta, Tenthredinidae) from Indonesia, Papua New Guinea, Malaysia and Vietnam, with keys to genera and species. Zoologische Mededelingen 80(2): 291-365. http://www.repository.naturalis.nl/document/41272

Malaise R (1944) Entomological Results from the Swedish Expedition 1934 to Burma and British India (Hymenoptera: Tenthredinoidea). Collected by René Malaise. The Tenthredinoidea of South-Eastern Asia. Subfamily II. Selandriinae. Arkiv för Zoologi 35 [1944-1945](3[A10]): 1-58.

Rodgers L, Bodle M, Black D, Laroche F, Pratt P, Boughton A, Renda M, Serbesoff-King K (2012) Status of Nonindigenous Species. South Florida Environmental Report 2012 (Chapter 7): 1-35. http://my.sfwmd.gov/portal/page/portal/pg_grp_sfwmd_sfer/portlet_ prevreport/2012_sfer/v1/chapters/v1_ch7.pdf

Saini MS (2006) Subfamilies Selandriinae and Dolerinae. In: Indian Sawflies Biodiversity. Keys, Catalogue \& Illustrations. Bishen Singh Mahendra Pal Singh, Dehra Dun 4: 1-167. Schmidt S, Smith DR (2009) Selandriinae, a subfamily of Tenthredinidae new to Australia, and a review of other Australian Tenthredinidae (Hymenoptera: Symphyta). Australian Journal of Entomology 48: 305-309. doi: 10.1111/j.1440-6055.2009.00710.x

Smith DR, Wright AD, Winotal A, Desmier de Chenon R (2002) Studies on Neostromboceros albicomus (Konow) (Hymenoptera: Tenthredinidae), a Potential Biological Control Agent for the Old World Climbing Fern, with Notes on Two Other Species of Neostromboceros. Journal of Hymenoptera Research 11(1): 142-151.

Taeger A, Blank SM, Liston AD (2010) World Catalog of Symphyta (Hymenoptera). Zootaxa 2580: 1-1064. http://www.mapress.com/zootaxa/2010/1/zt02580p1064.pdf 